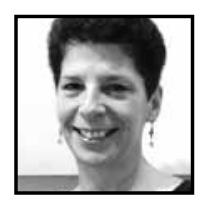

\title{
What Lies Beneath: Exploring Experiences of Faculty Learning From Informal Relationships
}

\author{
Anne Benoit, Curry College
}

\begin{abstract}
Programming to enhance teaching on college campuses often aligns with learning models that privilege formal and structured learning activities. This qualitative study explores the informal relational learning experiences of a small sample of faculty members in the Northeast United States. Participants' stories emphasize the relational nature of informal learning interactions which have the potential to result in perspective change. The findings highlight the value of trusting, ongoing interpersonal interaction and dialogue for meaningful faculty learning.
\end{abstract}

\section{Study Context}

igher education in the United States has been forced to respond to
criticisms related to perceived value versus cost, inadequate completion
and persistence rates, a lack of defined learning outcomes, lackluster teaching, and little data on student learning as a whole (Spellings Report, 2006; Arum \& Roksa, 2010; Hacker \& Dreifus, 2010). Internal and external pressures on the higher education sector are driving the need for teaching enhancement. In response, staff and administrators in university Centers for Teaching and Learning (CTLs) develop and deliver numerous programs designed to improve postsecondary instruction. However, despite efforts by faculty development centers to enhance faculty teaching, meaningful change in postsecondary teaching has been slow to arrive. 
The literature on structured faculty development programming in higher education is plentiful; however, there is little research that explores what lies beneath the explicit learning structures and programming designed to enhance postsecondary teachingthat is, the often invisible yet potentially powerful learning experiences that can result from informal faculty learning relationships.

\section{Study Purpose}

The purpose of this exploratory narrative study was to investigate the relational learning experiences of a small sample of college faculty members. To that end, data sets from a previous inquiry into faculty learning and development (Benoit, 2013) were re-analyzed using relational and transformative learning lenses to better understand the nature of faculty learning through informal relationships. Outcomes from the study have relevance for adult educators and academic/faculty developers in higher and further education.

\section{Theoretical Perspectives}

\section{Informal Learning}

Livingstone (2001) defines informal learning as "any activity involving the pursuit of understanding, knowledge, or skill which occurs without the presence of externally imposed curricular criteria" (p. 4). Informal learning may occur in conjunction with the pursuit of a specific goal or may result from an interaction that has no specific intention (Keeping, English, \& Fleming-Courts, 2001).

Coombs (1985) considers informal learning the most prevalent form of learning for adults. Informal learning, also known as everydaylearning, occurs in the daily professional interactions and interpersonal contexts within which adults live and work (Illeris, 2004). This type of learning takes place apart from the formal or institutionally sanctioned professional development programs that are available to faculty on college campuses.

Informal learning can occur or flourish in environments that are not considered particularly conducive to individual or organizational learning (Marsick \& Watkins, 1990). Moreover, informal learning can variably enhance or contradict learning acquired from disciplinary, departmental, or institutional sources (Schugurensky, 2000). 
Informal learning includes what Marsick and Watkins (2001) call incidental learning, which they define as learning that occurs as a by-product of some other activity. For example, a new faculty member working with a colleague on program or curriculum work "learns" through the interaction about departmental or institutional norms for role behavior, teaching culture, or assessment practices. Such learning would likely not be deliberate or intentional but instead a fortuitous outcome of an interaction designed for another purpose. Marsick \& Watkins (1990) note incidental learning is always happening even though most people are unaware of it and may not recognize it as learning.

\section{Adult and Professional Learning}

Cranton and King (2003) point to the tension adult educators must negotiate between addressing postsecondary teachers' immediate instructional needs and providing learning opportunities that speak to their development: "Professional development activities that focus on the how to rather than the broader issues of practice are an attempt to make knowledge about teaching instrumental" (p. 31). Brookfield (1986) also cautions against confusing adult learning with "learning how to perform at an improved level of competence in some pre-defined skill domain" (p. 99), as such a perspective raises questions related to who defines competence and which learning paradigm guides the assessment of improvement or mastery. Moreover, learning that involves knowledge transmission and skill enhancement-what Portnow, Popp, Broderick, Drago-Severson, and Kegan (1998) term informational learning-is very different from learning that leads to "deep and pervasive shifts in perspective and understanding" (p. 22).

\section{Transformative Learning}

Mezirow's (2000) theory of transformative learning, originally introduced in 1978, describes transformative learning as a process by which individuals change their habitual frames of reference to make them more discriminating, open, reflective, and emotionally capable of change. The expansion and enhancement of these frames occurs through what Mezirow (1990) terms perspective transformation, which he defines as "the process of becoming critically aware of how and why our presuppositions have come to constrain the way we perceive, understand, and feel about our world" (p. 14). The goal of perspective transformation is a reorganization of the structures through which a person views the self and his/her relationships, resulting in perspectives that are more inclusive, permeable, and integrated (Mezirow, 1991). 
Transformative learning theory has evolved into a complex and comprehensive theory of learning (Cranton, 1994). In the decades since Mezirow introduced the theory, Taylor (2008) has articulated what the theory body and empirical research suggest are interactive and necessary requirements for perspective transformation: voluntary and full participation in the learning, dialogue, and critical reflection on one's assumptions. Cranton (2006) and Dirkx (2006) have also identified a relational dimension in transformative learning which calls for trust-building and attention to the affective domain.

Mezirow (2000) suggests that learning theories need to acknowledge the important role of supportive relationships and a facilitating environment for adult learners, as learning that occurs within these contexts can support learners in identifying their own assumptions and building confidence to take action on new and emerging insights.

\section{Relational Learning}

For many, the term "relationship" connotes personal and intimate interactions with loved ones and partners. Whether mentioned in reference to faculty learning partnerships or faculty interactions with students, "relationship" in relational learning does not mean a romantic connection in the traditional sense; instead, it refers to the self-positioning that faculty members assume in their interactions-that is, how they "stand" in relation to their students, colleagues, and academic subjects.

A relational perspective on learning operates from the premise that learners come to know and to be through their relationships with others (Belenky, Clinchy, Goldberger, \& Tarule, 1986). Otero and Chambers-Otero (2000) contend that all learning occurs within relationships; however, because learning relationships are themselves variable, the quality of the learning that can result also varies. Cranton (2006) agrees that certain relationships create better conditions for learning and self-development than others.

The relational stance in its broadest sense has its origin in the work of philosopher Martin Buber (1958), who conceptualized that human beings variably enact their stance based on how they consciously or unconsciously perceive the "other" in an interaction. If the other is viewed from a perspective of "I-It," then Buber notes it is easy to treat the person with contempt or judgment. If, by contrast, the other is viewed through an "I-Thou" relational lens, then one is more likely to recognize commonalities, attend to the other from a place of stewardship, and speak or behave in ways that demonstrate the perceived value of the other. 


\section{Elements of the Facilitating Relationship}

Laurent Daloz (1986), whose foundational work with adult learners serves as the model for most adult educational mentoring frameworks, describes the relational context in adult learning as a dynamic space which must be deliberately cultivated and subsequently exists apart from the surrounding context. The relational context for the facilitating relationship must be solid enough to hold a learner's variable goals and experiences yet flexible enough to nurture ambitions and dimensions of self not yet conceived or realized. Daloz (1999) points to the power of attending to the other in the relational learning context, and in his work with adult learners, noticed the positive effect of his focused attention on his adult students and their learning. Being seen, being heard, and having the experience of being truly (even if only partially) understood by another whom the learner deems important constitute one source of facilitative support for adult learners.

The facilitating relationship is marked by three distinct components: Continuity, Confirmation, and Contradiction (Kegan, 1982). Continuity is established through sustained contact with a trusted significant other (Sullivan, 1953) and requires time, consistent interaction, and trust-building. The second component, confirmation, refers to the nature of the interpersonal interaction within the emotional context of the learning relationship. Confirming behaviors include the expression of acceptance, approval, and validation.

Trust-building through continuity, in combination with genuine confirmation, forms the relational context in which adults can risk deep learning and subsequent change (Cranton, 2006). Continuity and confirmation, then, comprise two components of what Kegan (1982) calls a holding space, within which learners are more likely to risk exposing their thinking and unexamined beliefs. Yet, confirmation and continuity alone will not move a learner to his/her "learning edge" (Berger, 2004). Contradiction is needed, and in the relational context, it represents the interpersonal conversations and dialogues that provide opposing views and alternative experiences which can challenge a learner's perceptions and assumptions. The necessary and judiciously applied balance of contradiction within the established relational context is a critical lever in the process of skillfully creating what Jarvis (2006) terms a "disjuncture"-an opening or gap in the learner's meaning system that occurs when a learner's articulated perspectives and knowledge claims are revealed as potentially incomplete or distorted (Gadamer, 1991). The three components of the facilitative relationship work interactively to create and sustain a catalyzing environment for adult learning and perspective change. 


\section{Methods}

The current study revisits data from a previous inquiry into the influences a sample of current college teachers identified as meaningful in their development as postsecondary teachers. Ten participants from the original study were identified through professional networks in the New England region, as well as through snowball sampling. The inclusion criteria called for the recruitment of active full-time faculty members from any academic discipline working in teaching-focused liberal arts colleges in the Northeast region of the United States holding faculty rank of assistant professor or above. After receipt of IRB approval, eight female and two male faculty members were interviewed for the full study. This inquiry re-analyzes the interview transcripts of three female faculty members using relational and transformative learning lenses; these particular transcripts were chosen because the participants specifically mentioned the role of informal workplace relationships in their learning as teachers. Table 1 provides participant demographic and professional information for the three participants.

\section{Table 1}

\section{Participant Demographic and Professional Information}

\begin{tabular}{|l|l|l|l|l|l|l|l|}
\hline PARTICIPANT & AGE & ETHNICITY & DISCIPLINE & $\begin{array}{l}\text { FACULTY } \\
\text { RANK }\end{array}$ & $\begin{array}{l}\text { YEARS } \\
\text { TEACHING }\end{array}$ & $\begin{array}{l}\text { DOCTORAL } \\
\text { DEGREE }\end{array}$ & $\begin{array}{l}\text { INSTRUCTIONAL } \\
\text { LEVEL }\end{array}$ \\
\hline Louisa & 39 & $\begin{array}{l}\text { Black } \\
\text { African }\end{array}$ & $\begin{array}{l}\text { American } \\
\text { Studies }\end{array}$ & $\begin{array}{l}\text { Associate } \\
\text { Professor }\end{array}$ & 10 & Ph.D. & Undergraduate \\
\hline Tara & 57 & Caucasian & Psychology & $\begin{array}{l}\text { Associate } \\
\text { Professor }\end{array}$ & 35 & Ph.D. & Undergraduate \\
\hline Valerie & 40 & $\begin{array}{l}\text { African } \\
\text { American }\end{array}$ & Biology & $\begin{array}{l}\text { Associate } \\
\text { Professor }\end{array}$ & 18 & Ph.D. & Undergraduate \\
\hline
\end{tabular}

\section{Data Collection}

Qualitative data was originally collected through single semi-structured interviews with each participant lasting between two and three hours. Demographic data was collected by means of a data sheet which participants completed prior to the interviews. In addition, Informed Consent documents were processed before interviews commenced. Field notes were taken during the interview sessions which were utilized during data analysis. 
Efforts were made to ensure the protection and anonymity of participants in this study: participant-chosen pseudonyms are used throughout, and little information related to participants' institutions is provided, as doing so might unintentionally expose participants' identities.

\section{The Research Approach}

Qualitative research emphasizes the discovery and interpretation of participants' experiences (Denzin \& Lincoln, 2000). A qualitative study was appropriate because of its potential to illuminate the interactive relationship between learning and experience (Bruner, 1965). Because this was an exploratory study that sought discovery, a standard literature review was not conducted prior to data analysis; moreover, analytic categories in the scholarly field were not previously identified so that the categories that emerged could be better grounded in the data, addressing the qualitative standard of confirmability (Guba \& Lincoln, 1998).

Narrative studies can provide access to reflective and retrospective meaningmaking (Chase, 2008). Participant narratives expressed through stories present a particular version of how life is experienced and understood (Webster \& Mertova, 2007). Yet, participant stories are not merely personal; they are influenced by the collective social, cultural, and professional narratives which inform the participants' thinking and practice. Further, Amsterdam and Bruner (2000) maintain that opportunities for narrative reflection provide insights into participants' practice not only as part of a larger or context-specific profession, but also as a way of thinking or "a way of life" (p. 282) in teaching.

\section{Data Analysis}

Upon completion of transcription, narrative summaries of the interview texts were composed and sent to each participant as a form of member checking (Lincoln \& Guba, 1985). Two cycles of coding were then performed on the original interview data. Firstcycle coding began with reading and re-reading each transcript. Key words and phrases were underlined, and notes based on the in vivo terms - the language that participants used in the interview texts-were made in the margins, which formed an initial set 
of codes. Field notes from the interviews were reviewed, and analytic memos were generated to explore the salience of the initial in vivo codes across cases.

In the second cycle, pattern coding (Saldaña, 2009) was performed to identify clusters of responses that suggest particular categories. Results of pattern coding were organized and placed in a thematic visual matrix which supports the identification of themes and also serves as a confirmatory check on emerging categories (Miles \& Huberman, 1994). Once all codes/themes fit comfortably within each evolving category and no new themes emerge, coding was considered complete and categories were finalized. The findings are discussed more broadly in light of the relevant literature.

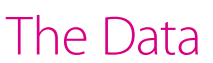

Participants' relational learning experiences clustered in three categories: Back Porch Conversations, Learning Conversations, and Self-Reflective Dialogues.

\section{Valerie, Associate Professor of Biology: Back Porch Conversations}

Valerie says of her relational learning experiences, "the most helpful for me have been the informal interactions." She characterizes her learning relationships with colleagues as back porch conversations that enhance the partners' mutual learning and provide opportunities for knowledge sharing:

I have dear colleagues that I talk with about our frustrations with the students. Through those conversations, we bring to the table different insights and points of view about what is going on with the students and why that might be happening. We also swap different ways that we can actually go about teaching. For example, one of my colleagues was having difficulty trying to explain a concept to a class of hers, and we were talking about why that was because they were not coming from an experience where they'd even have to think about the construct. So I actually gave her a strategy that I learned about that was very simplistic in nature but that really helped to illustrate the construct and how it actually affects people. So that was one of those 'back porch conversations' I like to talk about.

Valerie's colleagues have expanded her thinking in unexpected ways. Here she presents an example of an interaction with a trusted learning partner that opened a 
gap in her thinking and prompted her to inquire more deeply into an assumption she held about her faculty colleagues:

Sometimes we have to go to these talks on campus, and they are just abysmal. I was like, how did you not prepare for that talk? That's what's running through my mind: How did you not prepare? And it's completely horrible. And my friend was like, 'You know, not everyone can do what you can do. It's a talent and a skill.' And I was like, 'Oh, ${ }^{* * * \prime}$ (laughs). I had never thought of it like that before. But it was an assumption. I thought I was good about that because I try not to assume things about people based on their gender or race. I never thought about not assuming things about people based on intellect or academic prowess. I've learned not to just assume.

Another instance in which she relied on her learning partners to help her reframe an experience involved her reaction to receiving negative evaluations from her students in her early years at her current institution:

The first year, I came in with certain expectations of what these kids should be able to do. As a result, the evaluations were horrible, absolutely horrible. It was really embarrassing. My feelings were hurt, and I'm willing to admit that. I felt a little humiliated because the institution I came from before, all the kids loved me to death. So to get this blow that said, 'No, you're not as good as you think you are' kind of makes you want to change a little bit.

While the description might sound as if Valerie's response was rational and logical, leading to a painless resolution, she was quick to point out that the experience contained a strong emotional charge for her. She admits that she was angry both at herself and at her students and acknowledges that it would have been easy for her to blame the students and continue doing what she had been doing in her teaching. After working through her shock and discomfort, Valerie sought insights and advice from her trusted colleagues so that she could "do something with my pedagogy in order to better meet the needs of the students."

\section{Tara, Associate Professor of Psychology: Learning Conversations}

While Valerie's talks with colleagues about teaching are usually unplanned, Tara engages in what she identifies as frequent learning conversations with one or more trusted department members to process the day's teaching and learning experiences: 
We have professional conversations almost every day; you know, sometimes it's debriefing at the end of the day, or we talk with each other about different students-certainly keeping confidentiality-but exploring how did that work out or this really worked well today. We troubleshoot together if we get stuck, and you have somebody to 'think it through' with, so that's been helpful. I have those professional friends that I can talk to. We do it for each other, and we have these conversations-learning conversations, if you will.

In a previous learning partnership, Tara worked informally with another colleague in her department who had an extensive background in teaching and learning. Tara describes her learning from this interaction as significant, and here she articulates the impact of this interaction on her evolving conception of her teaching practice and stance:

We looked at all different kinds of teaching structures; we looked at everything from the banking model all the way from constructivist to transformative. I really had to stop and think about what kind of teacher I wanted to be and what kind of teacher my students needed me to be. I was in the position [then] where I saw myself as a 'partner' in their learning; I saw myself as working with students, but I was still in the power seat, still the expert. Then I learned about transformative learning, and I thought, 'Oh my God,' and really, all kinds of light bulbs went on for me, and I thought to myself, once again, I have to make another shift.

\section{Louisa, Associate Professor of American Studies: Self-Reflective Dialogues}

Louisa notes her interactions with her learning partners at her college have provided both a dialogic context for self-reflection and a learning space which has supported her in examining her beliefs about teaching:

It was talking to other people and hearing how they teach and also reframing the conversation-so changing it from 'My students can't do' to 'What ways can I help my students engage with.' I think that, for me, was a turning point, realizing [teaching] is an exchange. So there's more intentionality and thinking about the way you do the things you do; that has been what [my learning partners] really helped me with-just letting me process things.

Louisa mentions elsewhere that she worked informally on her teaching with a close colleague from another department, which provided her with valuable feedback on 
her teaching. She emphasizes, however, that her learning from the interaction would not have been possible without mutual trust and professional goodwill:

I was very welcoming of her in my class because we did trust each other-more correctly, I trusted her-I trusted her to be a 'good student'; I trusted her to do the things she said she was going to do, and then I got the benefit of her feeling like she could be open with me about my teaching-whether it was a positive or a negative thing.

Louisa's learning partners have enhanced her understanding of her own teaching. Here she recounts the content of a dialogue with a learning partner and includes her reflective insights gleaned during the interaction:

I always used power points, right? And [my learning partner] was like, 'Well, why do you use power points?' I said, 'Cause that's the best way to learn.' And she said, 'No, it's not. What do you use power point for?' And I was like, 'I don't know.' And she was like, 'Well, why do you use them?' And I said, 'Oh, if I don't use power points, I would just talk and talk and talk.' So I realized it was to organize myself; it wasn't for their learning. And then that made me realize that all my power points have pictures, not words, because the picture triggers the words for me. It doesn't trigger it for them. But it never even occurred to me. Until she asked me that, I never really thought about it. I thought, well, the pictures are just a really good way. If they've got the image, they can have a trigger. She was like, 'Well, why would it?' I was like, 'Of course! It works really well for me.'

\section{Discussion}

The purpose of the study was to examine experiences of informal faculty learning from relationships. Participant stories begin to offer insights into the informal relational learning of faculty members that occurs apart from structured faculty learning and development programs. This study adds an important but often unacknowledged dimension to current models of faculty learning not often addressed in studies of faculty development.

Valerie and Tara emphasize the role of significant others in their critical reframing, while Louisa identifies how her learning partners created not only a relational context for her reflection, but also an accepting space to process contradictory perspectives. 
Kreber (2004) characterizes reflection, especially reflection on the premises that underscore teachers' thinking and practice, as particularly difficult for educators but necessary for learning that has the potential to result in perspective change. Scribner and Donaldson (2001) identify a rigid focus on tasks and goals, a common practice in faculty learning programs, rather than reflective dialogue as a substantial barrier to significant adult learning.

Taylor (2007) acknowledges relational interaction as an important component of adult conceptual change. The salience of relational learning for perspective change identified in participants' experiences is supported by the literature in adult and transformative learning (Robertson, 1996; Saltiel \& Sgroi, 1996; Yorks \& Kasl, 2002; Choy, 2009; Stevens-Long, Shapiro, \& McClintock, 2012).

Sadler's (2008) study of teaching development in higher education also highlighted the role of colleagues in faculty learning. However, his participants emphasized the instrumental nature of the knowledge and strategies shared by faculty colleagues, a finding that aligns with the utilitarian category Carter (2002) identified in her study of workplace peer learning. In contrast, the participants in the current study indicated their learning relationships provided a nurturing interpersonal context for examining their assumptions.

Participants' stories point to the potential for informal relational dialogues to provide a context for the reflection required for perspective change, a finding which is consistent with the theoretical and empirical literature in adult and transformative learning (Daloz, 1986; Baumgartner, 2002; Carter, 2002; Dirkx, 2006; Taylor, 2008; Lysaker \& Furuness, 2011).

Participants in the current study described their learning interactions as marked by deep respect, acceptance, and valuing of the learning partners' experience and knowledge. Similar descriptions were also reported in the peer learning studies of Eisen (2001), Carter (2002), Gilly (2004), and Swartz and Triscari (2011).

A key feature of the participants' learning partnerships was an equitable relationship between peers. The mutual trust and admiration experienced by participants likely enhanced the development of a relational context for their learning. Further, the continuity and confirmation evident in their relational interactions and dialogues contributed to participants' openness and willingness to engage with contradictory information and opposing perspectives. 
While Tara's learning partnership occurred within a particular academic department, the other two participants' partnerships were cross-department and cross-disciplinary, providing increased opportunities for knowledge sharing and exposure to alternative viewpoints. Swartz and Triscari's (2011) self-study of their collaborative writing partnership also highlighted the value of the partners' disparate knowledge and experience and suggested these differences added richness and depth to their mutual yet variable learning.

\section{Study Limitations}

Several limitations are inherent in the study. Participants self-selected to be part of the original inquiry. Had male faculty members, as well as those from different academic disciplines, institutional categories, or career stages been included in the current study, the analysis would no doubt have produced different findings. In addition, no observations of participants' teaching were conducted, nor were learning relationship interactions observed. Therefore, participants' claims related to changes in beliefs or practices are limited to their comments and statements.

Despite these limitations, this inquiry was systematically planned and conducted. The quality of the data is supported by an audit trail which strengthens its findings and conclusions. Qualitative and narrative inquiry standards of trustworthiness were met through various strategies: member checking; analytic memoing; including data from field notes in the analysis; grounding interpretations in the data; and portraying participants and their learning experiences with rich and detailed description.

\section{Conclusions}

Change in teaching practice requires a change in perspective. Such change often involves a degree of loss and the release of sometimes long-held beliefs about the selfas-teacher and what has always been "true" in one's teaching practice. Peer learning partnerships that emerge from respectful friendships can support this transition by providing a developmental bridge (Kegan, 1994) between faculty learners' old way and new way of knowing and teaching. 
Those tasked with teaching enhancement in higher and further education should consider the value of alternative models of adult learning in their work with faculty, including relational and transformative theories of learning.

Faculty developers and center administrators should not assume that less than optimal attendance or participation in formal faculty learning events necessarily means that learning is not occurring on college campuses. Significant learning that supports perspective change can happen in numerous informal contexts and locales on college campuses-even on the back porch.

\section{References}

Amsterdam, A. G., \& Bruner, J. S. (2000). Minding the law: How courts rely on storytelling, and how their stories change the way we understand the law-and ourselves. Cambridge, MA: Harvard University Press.

Arum, R., \& Roksa, J. (2010). Academically adrift: Limited learning on college campuses. Chicago: University of Chicago Press.

Baumgartner, L. M. (2002). Living and learning with HIV/AIDS: Transformational tales continued. Adult Education Quarterly, 53(1), 44-59.

Belenky, M. F., Clinchy, B. M., Goldberger, N. R., \& Tarule, J. M. (1986). Women's ways of knowing: The development of self, voice, and mind. New York: Basic Books.

Benoit, A. (2013). Learning from the inside out: $A$ narrative study of college teacher development. Unpublished doctoral dissertation. Lesley University.

Berger, J. (2004). Dancing on the threshold of meaning: Recognizing and understanding the growing edge. Journal of Transformative Education, 2(4), 336-351.

Brookfield, S. (1986). Understanding and facilitating adult learning. San Francisco: Jossey-Bass.

Bruner, J. (1965). The art of discovery. In R. C. Anderson \& D. P. Ausubel (Eds.), Readings in the psychology of cognition (pp. 606-620). New York: Holt, Rinehart.
Buber, M. (1958). I and thou. New York: Scribner.

Carter, T. J. (2002). The importance of talk to midcareer women's development: A collaborative inquiry. The Journal of Business Communication, 39, 55-91.

Chase, S. (2008). Multiple lenses, voices, approaches. In N. K. Denzin \& Y. S. Lincoln (Eds.), Collecting and Interpreting Qualitative Materials, 3, 57-94.

Choy, S. (2009). Transformational learning in the workplace. Journal of Transformative Education, 7(1), 65-84.

Coombs, P. H. (1985). The world crisis in education: $A$ view from the eighties. New York: Oxford University Press.

Cranton, P. (1994). Understanding and promoting transformative learning: A guide for educators of adults. San Francisco: Jossey-Bass.

Cranton, P. (2006). Fostering authentic relationships in the transformative classroom. New Directions for Adult and Continuing Education, 111, 5-13.

Cranton, P., \& King, K. (2003). Transformative learning as a professional development goal. New Directions for Adult and Continuing Education, 98, 31-37.

Daloz, L. (1986). Effective teaching and mentoring. San Francisco: Jossey-Bass. 
Daloz, L. (1999). Mentor: Guiding the journey of adult learners. San Francisco: Jossey-Bass.

Denzin, N. K., \& Lincoln, Y. S. (2000). The discipline and practice of qualitative research. Handbook of Qualitative Research, 2, 1-28.

Dirkx, J. M. (2006). Engaging emotions in adult learning: A Jungian perspective on emotion and transformative learning. New Directions for Adult and Continuing Education, 109, 15-26.

Eisen, M. J. (2001). Peer-based professional development viewed through the lens of transformative learning. Holistic Nursing Practice, 16(1), 30-42.

Gadamer, H. G. (1991). Truth and method. New York: Crossroad.

Gilly, M. S. (2004). Experiencing transformative education in the corridors of a nontraditional doctoral program. Journal of Transformative Education, 2, 231-241.

Guba, E. G., \& Lincoln, Y. S. (1998). Competing paradigms in qualitative research. In N. K. Denzin \& Y. S. Lincoln, (Eds.), The Landscape of Qualitative Research (pp. 105-117). Thousand Oaks, CA: Sage.

Hacker, A., \& Dreifus, C. (2010). Higher education: How colleges are wasting our money and failing our kids-and what we can do about it. New York: Times Books.

Illeris, K. (2004). Adult education and adult learning. Malabar, FL: Krieger.

Jarvis, P. (2006). Towards a comprehensive theory of human learning. New York: Routledge.

Keeping, L. M., English, L. M., \& Fleming-Courts, N. (2001). Informal and incidental learning with patients who use continuous ambulatory peritoneal dialysis. Nephrology Nursing Journal, 28(3), 313-322.

Kegan, R. (1982). The evolving self: Problem and process in human development. Cambridge, MA: Harvard University Press.

Kegan, R. (1994). In over our heads: The mental demands of modern life. Cambridge, MA: Harvard University Press.

Kreber, C. (2004). An analysis of two models of reflection and their implications for educational development. International Journal for Academic Development, 9, 29-49.

Lincoln, Y. S., \& Guba, E. G. (1985). Naturalistic inquiry. Beverly Hills, CA: Sage.

Livingstone, D. W. (2001). Adult's informal learning: Definitions, findings, gaps and future research. NALL Working Paper \#212001. Retrieved from: http://www.nall/ca/ res/21adultsinformal learning.htm.

Lysaker, J., \& Furuness, S. (2011). Space for transformation: Relational, dialogic pedagogy. Journal of Transformative Education, 9(3), 183-197.

Marsick, V., \& Watkins, K. (1990). Informal and incidental learning. London: Routledge.

Marsick, V., \& Watkins, K. (2001). Informal and incidental learning. New Directions for Adult and Continuing Education, 89, 25-34.

Mezirow, J. (1978). Perspective transformation. Adult Education Quarterly, 28(2), 100-110.

Mezirow, J. (1991). Transformative dimensions of adult learning. San Francisco: Jossey-Bass.

Mezirow, J., \& Associates. (1990). Fostering critical reflection in adulthood: $A$ guide to transformative and emancipatory learning. San Francisco: Jossey-Bass.

Mezirow, J., \& Associates (Eds.) (2000). Learning as transformation: Critical perspectives on a theory in progress. San Francisco: Jossey-Bass.

Miles, M. B., \& Huberman, A. M. (1994). Qualitative data analysis: An expanded sourcebook. Thousand Oaks, CA: Sage.

Otero, G. G., \& Chambers-Otero, S. (2000). Relational Learning: Towards a Human Ecology in 21st Century Schools. Jolimont, BC: Incorporated Association of Registered Teachers of Victoria.

Portnow, K., Popp, N., Broderick, M., Drago-Severson, E., \& Kegan, R. (1998). Transformational learning in adulthood. Focus on Basics, 2, 22-27.

Robertson, D. (1996). Facilitating transformative learning: Attending to the dynamics of the educational helping relationship. Adult Education Quarterly, 47, 41-53. 
Sadler, I. (2008). Development of new teachers in higher education: Interactions with students and other influences upon approach to teaching. Unpublished dissertation. The University of Edinburgh.

Saldaña, J. (2009). The coding manual for qualitative researchers. Thousand Oaks, CA: Sage.

Saltiel, I., \& Sgroi, A. (1996). The power of the partner in adult learning. Presentation at the American Association for Adult and Continuing Education Conference. Charlotte, N. C.

Schugurensky, D. (2000). The forms of informal learning: Towards a conceptualization of the field. NALL Working Paper \#19-2000. Retrieved from: http://www.nall.ca/res/19 formsofinformal.htm

Scribner, J. P., \& Donaldson, J. F. (2001). The dynamics of group learning in a cohort: From non-learning to transformative learning. Educational Administration Quarterly, 37, 605-636.

Spellings Report on the Future of Higher Education. (2006). A test of leadership: Charting the future of U.S. higher education. Washington, DC: U.S. Department of Education.
Stevens-Long, J., Shapiro, S. A., \& McClintock, C. (2012). Passionate scholars: Transformative learning in doctoral education. Adult Education Quarterly, 62(2), 180-198.

Sullivan, H. S. (1953). The interpersonal theory of psychiatry. New York: Norton.

Swartz, A. L., \& Triscari, J. S. (2011). A model of transformative collaboration. Adult Education Quarterly, 61(4), 324-340.

Taylor, E. W. (2007). An update of transformative learning theory: A critical review of the empirical research (1999-2005). International Journal of Lifelong Education, 26, 173-191.

Taylor, E. W. (2008). Transformative learning theory. New Directions in Adult and Continuing Education, 119, 5-15.

Webster, L., \& Mertova, P. (2007). Using narrative inquiry as a research method: An introduction to using critical event narrative analysis in research on teaching and learning. New York: Routledge.

Yorks, L., \& Kasl, E. (2002). Learning from the inquiries: Lessons for using collaborative inquiry as an adult learning strategy. New Directions for Adult and Continuing Education, 94, 93-104.

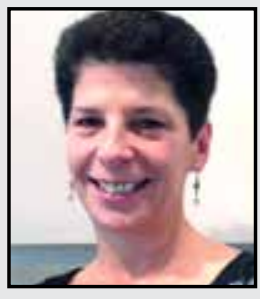

Anne Benoit, Ph.D., is currently Senior Lecturer and Coordinator of Undergraduate Peer Tutor \& TA Programs at Curry College in Milton, Massachusetts. Anne has worked with both traditional undergraduate and adult students at several institutions and has taught in a variety of learning contexts, including $\mathrm{K}-12$, community corrections, and higher education. Her forthcoming article in New Directions for Teaching and Learning (2015) examines adult transformation through critical learning events. Anne is the recipient of the 2014 AERA SIG-FTED Robert J. Menges New Researcher Award.

LINK TO:

http://www.curry.edu/directory-bios/benoit-anne-c.html

https://www.academia.edu/AnneBenoit 